\title{
Mapping GDP and PPPs at Sub-National Level Through Earth Observation in Eastern Europe and CIS Countries
}

\author{
M. Simona Andreano ${ }^{\text {a)}}$, \\ Roberto Benedettib), \\ Federica Piersimonic), \\ Giovanni Saviod) \\ a) Mercatorum University, Rome, Italy; \\ b) D'Annunzio University of Chieti-Pescara, Pescara, Italy; \\ c) Italian National Institute of Statistics (Istat), Rome, Italy; \\ d) United Nations Economic Commission for Latin America and the Caribbean (UN-ECLAC), Santiago de \\ Chile, Chile
}

Following the line of research, originated from the paper by Henderson et al. (2012), this article focuses on how "observations from the above”, in the form of night-lights satellite data, might contribute in mapping at very fine geographical level (ideally, one square km), two core macroeconomic indicators used extensively in the Sustainable Development Goals monitoring and reporting framework: Gross Domestic Product (GDP) and Purchasing Power Parities (PPPs). Recent empirical economic studies have paid increasing attention on the association between night-lights observations and economic growth, in order to estimate a consistent and objective level of economic activities at subnational level.

In the present paper, analyses are carried out on a panel of 17 Eastern Europe and CIS countries for the period 2000-2013 and use is made of indicators constructed from satellite images in the form of night lights, as processed by the US Department of Defense, and its Defense Meteorological Satellite Program's Operational Linescan System. Estimations of GDP in current US dollars and PPP terms are carried out at both national and sub-national level, and results are compared with the official available information. Estimates of GDP and PPP were also compared, at national level, with those in the World Bank data-set, showing similar behaviours. Results are used to obtain gridded maps of GDPs and PPPs.

Keywords: night-time lights, GDP, PPP, CIS countries, panel model.

JEL: C23, E01, E23, E30, O11, O47.

doi: https://doi.org/10.34023/2313-6383-2019-26-11-70-84.

For citation: Andreano M.S., Benedetti R., Piersimoni F., Savio G. Mapping GDP and PPPs at Sub-National Level Through Earth Observation in Eastern Europe and CIS Countries. Voprosy Statistiki. 2019;26(11):70-84. (In English)

\section{Картирование ВВП и ППС на субнациональном уровне \\ на основе спутниковых снимков территории стран \\ Восточной Европы и СНГ}

\author{
М. Симона Андреано ${ }^{\text {a), }}$ \\ Роберто Бенедетти \\ Федерика Пьерсимони ${ }^{\mathrm{B}}$, \\ Джованни Савио \\ a) Университет Меркаторум, г. Рим, Италия; \\ б) Университет им. Г. Д’Аннунцио Кьети-Пескара, г. Пескара, Италия; \\ в) Национальный институт статистики Италии (Истат), г. Рим, Италия; \\ г) Экономическая комиссия ООН для Латинской Америки и Карибского бассейна (ЭКЛАК), \\ г. Сантьяго-де-Чили, Чили
}


Продолжая линию исследований, ведущую свое начало от опубликованной в 2012 г. работы Дж. Хендерсона и др., авторы в данной статье сосредоточили свое внимание на том, как «наблюдения сверху», а именно спутниковые данные о ночном освещении, могут быть использованы в точном географическом картировании (в идеале - до одного квадратного километра) двух основных макроэкономических показателей, широко используемых в системе мониторинга достижения Целей в области устойчивого развития и формирования отчетности: валового внутреннего продукта (ВВП) и паритетов покупательной способности валют (ППС). Последние эмпирические экономические исследования свидетельствуют о растущем интересе $\kappa$ связи между наблюдаемыми ночными огнями и экономическим ростом, на основе которой можно последовательно и объективно оценить экономическую деятельность на субнациональном уровне.

В данной статье проводится анализ индикаторов, полученных из спутниковых снимков ночных огней и обработанных Министерством обороны США при помощи его сканирующей системы OLS (Operational Linescan System) Оборонительной метеорологической спутниковой программы (DMSP), для 17 стран Восточной Европы и СНГ за период 2000-2013 гг. Оценки ВВП в долларах США по текущему обменному курсу и ВВП, рассчитанного по ППС, осуществляются как на национальном, так и на субнациональном уровнях, а результаты сравниваются с имеющейся официальной информацией. Также сопоставлялись оценки ВВП и ППС (на национальном уровне) с данными Всемирного банка, и было выявлено аналогичное сходство. Результаты использовались для получения привязанных к сетке карт ВВП и ППС.

Ключевые слова: ночные огни, ВВП, ППС, страны СНГ, модель панельных данных.

JEL: C23, E01, E23, E30, O11, O47.

doi: https://doi.org/10.34023/2313-6383-2019-26-11-70-84.

Для цитирования: Андреано М.С., Бенедетти Р., Пьерсимони Ф., Савио Дж. Картирование ВВП и ППС на субнациональном уровне на основе спутниковых снимков территории стран Восточной Европы и СНГ. Вопросы статистики. 2019;26(11):70-84. (На английском языке)

\section{Introduction}

The adoption of the Sustainable Development Goals in September 2015 by the United Nations General Assembly is calling National Statistics Offices (NSOs) worldwide to underpin a data revolution, as they are asked to extend both the scope and disaggregation of the data traditionally produced, and measure new economic, social and environmental phenomena, leaving none behind.

There is a growing consensus in the digital era that Big Data, particularly satellite images captured from the above, might strengthen the capacity of traditional data sources and official statistics to help in monitoring sustainable well-being, thus facing the increasing request for more spatially disaggregated data.

Following the line of research originated from the paper by Henderson et al. [1], this article focuses on how «observations from the above», in the form of night-lights satellite data, might contribute in mapping at very fine geographical level (ideally, one square $\mathrm{km}$ ), two core macroeconomic indicators used extensively in the Sustainable Development Goals (SDG) monitoring and reporting framework: GDP and PPPs.

Nowadays, the use of night-light as proxy of GDP has becomes a standard in empirical economics (see, e. g., [2, 3]). The obvious advantage in using night lights is that they generally show a good correlation with GDP, they are available for free and for a long time span, and they are objectively measured.
This research uses extensively the set of information coming from satellite images, as processed by the US Department of Defense, and its Defense Meteorological Satellite Program's Operational Linescan System (DMSP-OLS). Scientists at the National Geophysical Data Center (NGDC) process these raw data and distribute the final set to the public, thus making freely available 34 annual products from six satellites spanning 22 years, from 1992 to 2013. However, given the proximity of the first data available for satellites with the dissolution of the Soviet Union and the length of the transition period in the economies of the region, the sample analysed in this paper goes from 2000 to 2013.

The stable night lights are those used in this research to proxy GDP in nominal and PPP terms for 17 CIS and Eastern Europe countries: Azerbaijan, Armenia, Belarus, Bulgaria, Czechia, Hungary, Kazakhstan, Kyrgyzstan, Poland, Moldova, Romania, Russian Federation, Slovakia, Tajikistan, Turkmenistan, Ukraine and Uzbekistan.

Henderson et al. were the first to use night lights in a complete statistics and econometric framework to estimate, in a panel of world time series, real economic growth. Following their examples, the relation between lights and GDP at sub-national administrative levels have been deeply investigated for North Korea, Kenya, Rwanda, Sweden, Nigeria, India and China.

More recently, while some papers have confirmed the ideas underlying the lights-to-GDP hypothesis at the country level (see, e. g., [4]), the approach used 
by [1] have been criticized due to the implicit assumption of stable elasticity made in obtaining sub and/or supra-national estimates $[5,6]$, which is hardly met under common situations where a modifiable area unit problem (MAUP) exists. Particularly, it has been stressed that the elasticity of GDP-to-lights should be statistically significant and positive, as well as temporally and spatially stable.

For CIS and Eastern Europe countries, the literature on lights and GDP is practically non-existent, the only indirect reference being a global exercise carried out by Elvidge et al. [4] on the correlation (in levels) between GDP, night lights and population at national level during 1992-2012. Furthermore, to the best of our knowledge, no study has been so far carried out on the direct or indirect relation between lights and PPPs.

Our paper innovates with respect to the preceding literature in at least three respects. First, it analyses in a systematic way the relationship between DMSPOLS night lights and GDP in CIS and Eastern Europe countries at the finer extent possible, looking at conditions under which lights can be used to obtain estimates of GDP and PPPs at detailed geographical level.

Second, the research uses both a time and spatial approach in the analysis, particularly through the use of balanced panel regressions models, and tests the conditions of spatially and time stability of GDP-tolight elasticity.

Third, use is made of the available national and subnational data produced by NSOs of the region. After testing for the existence of temporally and spatially stable elasticity of GDP both in real and PPP terms with respect to lights, the estimated coefficients are used to map economic activity and parities at very fine geographical level, thus offering two sets of information that are mostly needed for SDGs monitoring and reporting.

We are fully aware that the estimations provided in this paper cannot replace primary statistics produce by NSOs of the region. However, we hope these estimates will be of some use for policy makers and researchers for their policy intervention, analyses and discussion, and contribute in partially answering the increasing demand for more spatially disaggregated macroeconomic data to further advance the sustainable development agenda.

The scheme of the paper is as follows. The next section describes the main characteristics of the DMSP system and the satellite information obtained in terms of night lights. Section 3 details on the indices considered in empirical analyses, the transformation carried out on night-lights information and the population data used. Section 4 follows with the results of the empirical applications. The last Section of the paper summarizes main results and concludes.

\section{Night-Lights Data from Satellite Images}

Earth observation have been used in many respects to shed light on specific aspects of human development, such as economic output, population, urbanization, land, water and natural resources use, weather conditions and climate change, and pollution monitoring.

In parallel, there has been a growing use of night lights, one of the most important by-products of satellite remote sensing, as proxy for measuring economic, social and environmental phenomena.

This paper makes an extensive use of the set of information coming from satellite images, as processed by the US Department of Defense, and its Defense Meteorological Satellite Program's Operational Linescan System, see [7, 8] on technical aspects of the programme and, for a survey on use of such images [9].

A characteristic of DMSP-OLS data that has attracted most attention of researcher in the last years is their availability at a very fine geographical level (1 square $\mathrm{km}$ ), thus making it possible to estimate through them a number of statistics at sub-national level, particularly those related to the level and growth of economic activity, thus providing an answer to chronicle lack of official statistics at the level of disaggregation requested within the framework of the sustainable development agenda.

The Defence Meteorological Satellite Program (DMSP) is a Department of Defence program of the US Air Force Space and Missile Systems Center, which started to capture imagery in the early 1970s through the Operational Linescan System (OLS) sensor. One of the primary objectives of the OLS sensors was to collect worldwide cloud cover observations twice per day.

In 1992 the National Oceanic and Atmospheric Administration (NOAA) was established and it processed and archived the DMSP night-time light satellite imagery for 22 years. The DMSP programme has been repeatedly upgraded over time, with the latest series in its Version 4 spanning data for the years 1992-2013 and actually publicly available from NOAA from its website (https://www.ngdc.noaa.gov/eog/ dmsp/downloadV4composites.html). Satellites from DMSP-OLS measure light emissions in the evening 
hours between 8:30 and 10:00 pm local time around the globe every day.

The OLS sensor has two broadband sensors, in the visible/near-infrared (VNIR, 0.4-1.1 $\mu \mathrm{m}$ ) and thermal infrared (10.5-12.6 $\mu \mathrm{m})$ wavebands. The OLS is an oscillating scan radiometer with a broad field of view $(\sim 3,000 \mathrm{~km}$ swath) and captures images at a nominal resolution of $0.56 \mathrm{~km}$, which is smoothed on-board into $5 \times 5$ pixel blocks to $2.8 \mathrm{~km}$.

Scientists at the National Oceanic and Atmospheric Administration's National Geophysical Data Center process these raw data and distribute the final data to the public, following an undertaking of monumental difficulty. Original data are from the centre half of the $3000 \mathrm{~km}$ wide OLS swaths.

NGDC recently reprocessing of the DMSP time series have produced 34 annual products from six individual sensors on satellites, called $\mathrm{F}$, spanning 22 years: F10 (1992-1994), F12 (1994-1999), F14 (1997-2003), F15 (2000-2008), F16 (2004-2009), and F18 (2010-2013). This is referred to as the Version 4 DMSP stable lights time series, the ones used here for GDP and PPP analysis.

Lights in the centre half have better geo-location, are smaller, and have more consistent radiometry. In processing the raw data, a number of filters are applied before releasing final results. Sunlit data are excluded based on the solar elevation angle. Glare is also excluded based on solar elevation angle. Moonlit data are omitted based on a calculation of lunar luminance [7, 10].

The recorded daily data are pre-processed, by removing observations of cloudy days and sources of lights which are not man-made, such as auroral lights or forest fires.

Data from all orbits of a given satellite in a given year are then averaged over all valid nights to produce a satellite-year dataset. These are the datasets that are distributed to the public. As a result, each satellite-year dataset reports annual light intensities for every pixel around the globe at a resolution of 30 by 30 arc seconds (approximately 0.86 square $\mathrm{km}$ at the equator) between 65 degrees $\mathrm{S}$ and 75 degrees $\mathrm{N}$ latitude.

Data are released in three different versions: raw, stable lights and the calibrated versions. The stable lights version removes ephemeral events such as fires and background noise, and contains the lights from cities, towns, and other sites with persistent lighting, including gas flares. The calibrated version is currently available only for 2006 and has the advantage of not being saturated (top-coded).
Our analyses are based on the stable lights version. Data made available to the public by the NOOA have been geo-referenced at national and regional levels by digital number (DN) using the administrative areas and boundaries (level 0 and 1, respectively) provided in the form of shape-files by GADM, Version 3.6, available at https://www.gadm.org. A geolocation algorithm was used to map the data onto the $1 \mathrm{~km}$ grid developed for the NASA-USGS Global $1 \mathrm{~km}$ AVHRR project, that limit error in geolocation in the project process.

The light intensity values of the stable lights product are recorded in a fixed range of digital numbers from 0 (missing or completely dark) to 63 (bright). Sensor saturation implies that the satellites are not able to capture a light intensity higher than $63 \mathrm{DN}$. A small fraction of pixels, generally in rich and dense city areas, have $\mathrm{DN}$ values equal to 63 .

The saturation and blooming issues in DMSP-OLS NTL images are the main limiting factors in their use. Imagery from the DMSP-OLS satellite has a tendency to overestimate NTL imagery, an effect generally referred to as «blooming» in the literature. Blooming occurs when cells producing NTL cause lit pixels to extend beyond the source's true illuminated area. This phenomenon can be acute in OLS imagery and it is more pervasive over water and snow areas, as these reflect close lights more than dark ground. Blooming should be of particular concern when examining coastal metropolises, since changes in brightness tend to be bigger in area than associated land cover changes [11]. Typically, blooming is proportional to the SOL emitted by a light source, such as an urban area.

Sensor settings vary over time across satellites and with the age of a satellite, so that comparisons of raw DN over years can be problematic. This explains why satellites, in the very last years, are replaced by new ones, accompanying them for their last few years of life. That happened for all satellites but the last, F16, substituted by the last orbiting F18 without an overlapping period. A map of night lights for Europe, including Eastern Europe and CIS countries, is represented in Figure 1 below.

There are several studies aimed at radiance calibration of DN over time across satellites (e. g., [12] and the literature cited therein). Their goal is to make data comparable across time, creating a consistent time series of satellite observation that eliminates abrupt jumps in the series, when passing from observations of one satellite to another. DMSP light data collected in different years (and satellites) may have variations 


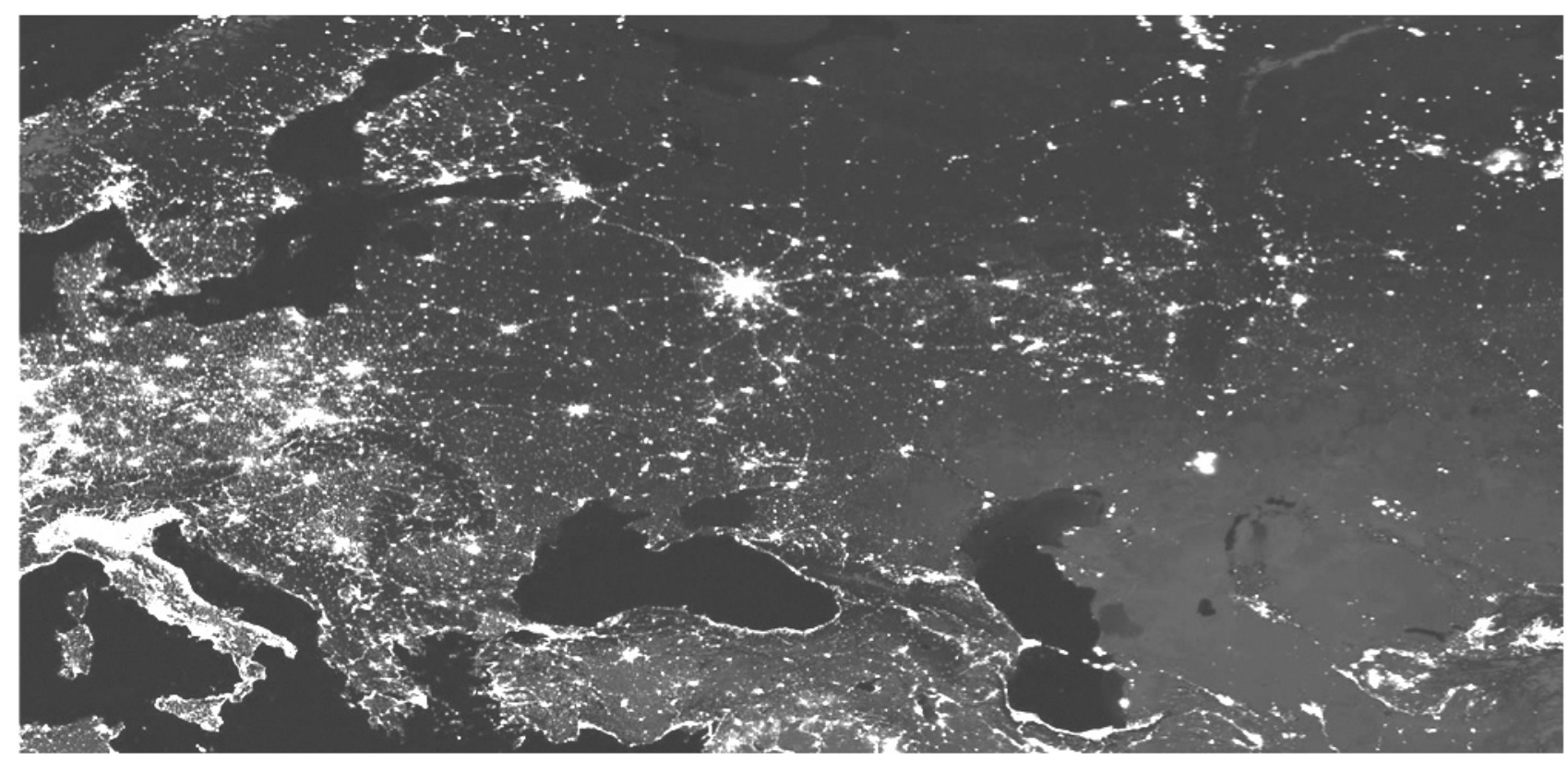

Figure 1. Plot of Night Lights of Eastern Europe and CIS Countries (2011)

in gain settings, sensor degradation, and change in atmospheric condition.

We did not perform such calibration on the original data, but we control for such issues, whenever appropriate, by using panel regression estimations with fixed effects for time and satellites. Such estimations are able to take into considerations the differences in the capacity of satellites to identify lights intensity due to obsolescence.

For years with two satellite observations, the arithmetic average of the two outcomes is considered in the empirical applications.

The DN is not exactly proportional to the physical amount of light received (called true radiance) for several reasons. The first is sensor saturation, which is analogous to top-coding. Further, the scaling factor ("gain") applied to the sensor in converting it into a digital number varies for reasons that are not explained, possibly to allow Air Force analysts to get clearer information on cloud cover.

Unfortunately, the level of gain applied to the sensor is not recorded in the data. The DMSP night-time lights provide the longest continuous time series of global urban remote sensing products, now spanning 22 years. The flagship product is the stable lights, an annual cloud-free composite of average digital brightness value for the detected lights, filtered to remove ephemeral lights and background noise.

The follow on to DMSP for global low-light imaging of the earth at night is the Visible Infrared Imaging Radiometer Suite (VIIRS) Day/Night Band (DNB), flown jointly by the same NASA-NOAA Suomi Na- tional Polar Partnership launched in 2011. These data are available for a shorter time period (data are indeed available on a monthly basis only from 2012 onwards, annually only for 2015-2016), but they are of greater precision than DMSP images and made available to public in a very timely way, after some few days from the end of each month. They offer substantial improvements in spatial resolution, radiometric calibration and usable dynamic range when compared to the DMSP low light imaging data.

VIIRS DNB key improvements over DMSP-OLS data include a vast reduction in the pixel footprint (15 arc-second, about $500 \mathrm{~m}$ ), uniform ground instantaneous field of view from nadir to edge of scan, lower detection limits, wider dynamic range, finer quantization, in-flight calibration and no saturation [10]. Prior to averaging, the DNB data is filtered to exclude data impacted by stray light, lightning, lunar illumination, and cloud-cover. Cloud-cover is determined using the VIIRS Cloud Mask product.

\section{GDP, PPPs and Explanatory Variables}

The data on GDP are obtained from the World Bank, World Development Indicators database, which contains data by country on different measures of national accounts. Those used in this paper include current local currency unit data, current US dollars data, and data in PPPs (current international US dollars). PPPs time series can be obtained implicitly by dividing current data in local currency by the corresponding data expressed in PPP, in current international US dollars. 
An alternative indicator often used as proxy for GDP is electricity consumption. We consider here an electric power consumption ( $\mathrm{kWh}$ per capita) indicator obtained from the World Development Indicators database.

Night-lights data have been used to derive a number of indicators applied in the empirical analyses, as follows. Let us indicate with $V_{i}$ the $D N$ value, ranging from $0.5^{1}$ to 63 , and with $N_{i j}$ the number of pixels with a $D N$ value equal to $V_{i}$ in country $i$. The sum $(S L)$, mean $(M L)$, and standard deviation $(S D L)$ of lights for country $i$ are defined as:

$$
\begin{aligned}
& S L_{i}=\sum_{j=1}^{K_{i}} V_{j} \times N_{i j}, M L_{i}=\frac{S L_{i}}{\sum_{j=1}^{K_{i}} N_{i j}}, \\
& S D L_{i}=\sqrt{\frac{1}{\sum_{j=1}^{K_{i}} N_{i j}} \sum_{j=1}^{K_{i}}\left(V_{j}-M L_{i}\right)^{2} N_{i j}}, \\
& i=1,2, \ldots, 17,
\end{aligned}
$$

where $K_{i}$ is the number of $D N$ values with pixels different from zero and may be maximum 63 , in case of one satellite and maximum 126 for two satellites. In case of a single satellite, the values of $V_{i}$ may be $1,2, \ldots, 63$, although not all these have frequencies $N_{i j}$ different from zero. In years with two satellites, $V_{i}$ may also assume intermediate values $0.5,1.5$, $2.5, \ldots, 62.5$ and therefore, $K_{i}$ can be at most 126. The index $i$ refers to $V_{i}$ with pixel greater than zero and $i=1,2, \ldots, K_{i}$. The indicators were computed distinctly for each of the twenty countries $(i=1,2, \ldots, 17)$.

Among the indicators constructed using nightlights information, we considered a Gini night-light index. The index measures the extent to which the distribution of light intensities (in terms of DN) among pixels (the Lorenz curve of the traditional Gini index), deviates from a perfectly equal distribution. The Gini index measures the area between the Lorenz curve and this hypothetical line of absolute equality, expressed as a percentage of the maximum area under the line. Thus, a Gini index of 0 represents perfect equality, while an index of 1 implies perfect inequality.

The data set used in analyses includes also population data, which are extracted from the World Bank national and sub-national population total estimates of the de facto mid-year population at national and first level administrative division.
We construct the Gini coefficient using only information from night-light as per the formulas below, where it is assumed that the $V_{j}$ 's represent values of lightsand the $N_{j}$ 's the pixels pertaining to those values.

The Gini index [13] is defined as follows:

$$
G N_{i}=\frac{\sum_{l=1}^{K_{i}} \sum_{j=1}^{K_{i}}\left|V_{l}-V_{j}\right| N_{i l} N_{i j}}{2 K_{i} \sum_{l=1}^{K_{i}} N_{i l}} \quad i=1,2, \ldots, 20,
$$

with $K_{i}$ defined in previous formulas.

As an alternative to the Gini, we also consider the Bonferroni inequality index [14], a measure based on the comparison of the partial means $M L_{i}^{h}$ and the global mean $M L_{i}$ of the lights distribution of country $i$ :

$$
\begin{gathered}
B F_{i}=\frac{1}{K_{i}-1} \sum_{h=1}^{K_{i}-1} \frac{\left(M L_{i}-M L_{i}^{h}\right)}{M L_{i}}= \\
=1-\frac{1}{K_{i}-1} \sum_{h=1}^{K_{i}-1} \frac{M L_{i}^{h}}{M L_{i}}, \\
M L_{i}^{h}=\frac{\sum_{j=1}^{h} V_{j} N_{i j}}{\sum_{j=1}^{h} N_{i j}} .
\end{gathered}
$$

Compared to the Gini, the Bonferroni index has a number of advantages, see e. g. [15], most notably it is more sensitive at the lower tail of the income (light) distribution, where indeed night lights are concentrated in our sample: this is a common feature of most countries around the world, see [1]. The Gini and Bonferroni indices are defined over the interval $[0,1]$, with lower and upper limits reached in case of perfectly equal and concentrated distributions of lights in the extremes of the definition interval. The indices are supposed to have positive correlation with GDP measures, and $B F \geqslant G N$.

Other less used measures of concentration considered in this paper are the Mean Log Deviation, $M L D$, and the first, second and third quartiles of the lights distribution, as well as the inter-quartile difference, $I Q D$, which have straightforward definitions.

Other less used measures of concentration considered in this paper are the Mean Log Deviation, $M L D$, and the first, second and third quartiles of the lights distribution, as well as the inter-quartile difference, $I Q D$, which have straightforward definitions.

\footnotetext{
${ }^{1}$ Non-integer values may occur in years where two satellites are available (the final image value $D N$ is equal to the average of the two values captured by the satellites orbiting during the same calendar year).
} 
We also follow other authors in considering, as possible explanatory variables, indices aimed at measuring the extent of urbanization in the countries analysed. In this respect, it is quite common to use a threshold of $D N=7$ or $D N=10$, e. g. [16], as the values to discriminate between urban and non-urban areas. The first index, the Urban Light Index, ULI, has been proposed by [17]:

$$
U L I_{i}=100 \times \sum_{j=70 r 10}^{K_{i}} \frac{V_{j}}{\max \left(V_{j}\right)} \times \frac{N_{i j}}{\sum_{j=1}^{K_{i}} N_{i j}},
$$

where $N_{i j}$ and $\sum N_{i j}$ are the pixels with $V_{j}$ and the total of lit pixels, respectively. Here, $\frac{V_{j}}{\max \left(V_{j}\right)}$ indicates the brightness, \[ \max \left(V_{j}\right) \]
which reflects the light intensity of each area, while $\frac{N_{i j}}{\sum N_{i j}}$
reflects the weight of $V_{j}$.

Finally, as an alternative indicator of urbanization, we consider in our analyses the Night Light Index, $N L I$, and its two subcomponents, the Mean Light Intensity Index, $M L I I$, characterizing light intensity, and the Light Area Index, $L A I$, characterizing the light spatial distribution of each area. This is an index originally proposed by Yang et al. [18], and it is supposed to accommodate for three main factors affecting the degree of urbanization: urban population, industrial structure, and build-up area distribution. The index and the components are defined as follows:

$$
N L I_{i} \equiv M L I I_{i} \times L A I_{i}=\frac{\sum_{j=1}^{K_{i}}\left(V_{j} \times N_{i j}\right)}{63 \sum_{j=1}^{K_{i}} N_{i j}} \times \frac{\sum_{j=1}^{K_{i}} N_{i j}}{\sum_{j=0}^{K_{i}} N_{i j}} .
$$

In computing the $L A I_{i}$ index, the sum of pixels at the denominator includes also those with $D N=0, N_{i 0}$. $M L I I_{i}$ is the ratio of the observed lights compared to its potential maximum value (i. e. the value obtainable if all pixels were saturated and therefore with only $D N$ equal 63): it represents a measure for light intensity. $L A I_{i}$ is the percentage of lit pixels over total area (lit and unlit) of the country $i$.

A sense of our data-set is provided by the statistics for GDP and some derived night-lights indicators for the 17 Eastern Europe and CIS countries considered, as reported in Table 1.

Table 1

Main Statistics of Night Lights and GDP, Averages over the Available Years, 2000-2013

\begin{tabular}{|l|c|c|c|c|c|c|c|c|c|}
\hline \multicolumn{1}{|c|}{ Statistics } & Armenia & Azerbaijan & Bulgaria & Belarus & Czechia & Hungary & Kazakhstan & Kyrgyzstan & Moldova \\
\hline$\%$ Area unlit $(D N=0)$ & 78.4 & 70.2 & 46.0 & 70.8 & 5.0 & 36.8 & 95.0 & 91.7 & 57.5 \\
\hline $\begin{array}{l}\% \text { Urban area } \\
(10 \leqslant D N \leqslant 63)\end{array}$ & 22.3 & 18.3 & 14.5 & 19.9 & 43.6 & 28.9 & 20.3 & 19.5 & 9.8 \\
\hline$\%$ Top-coded area $(D N=63) *$ & 0.95 & 0.46 & 0.42 & 0.49 & 1.36 & 1.27 & 0.11 & 0.04 & 0.02 \\
\hline Mean $(D N)$ & 8.79 & 8.00 & 6.97 & 8.19 & 12.47 & 10.21 & 8.54 & 7.81 & 5.92 \\
\hline St. Dev. $(D N)$ & 9.73 & 9.26 & 7.13 & 8.80 & 10.23 & 9.94 & 10.03 & 7.68 & 6.16 \\
\hline Second quartile $(D N)$ & 5.6 & 5.0 & 4.9 & 5.6 & 8.9 & 6.6 & 5.2 & 5.3 & 4.5 \\
\hline Gini $(D N)$ & 0.436 & 0.446 & 0.382 & 0.429 & 0.378 & 0.419 & 0.470 & 0.393 & 0.363 \\
\hline Bonferroni $(D N)$ & 0.521 & 0.523 & 0.462 & 0.507 & 0.473 & 0.507 & 0.546 & 0.477 & 0.431 \\
\hline $\begin{array}{l}\text { Population density } \\
\text { (population/pixel) }\end{array}$ & 65.3 & 65.7 & 54.6 & 18.8 & 73.0 & 63.3 & 3.3 & 17.1 & 61.9 \\
\hline $\begin{array}{l}\text { GDP per capita, PPP } \\
\text { (constant 2011 international \$) }\end{array}$ & 5730 & 11057 & 12791 & 13136 & 26147 & 21740 & 17071 & 2555 & 4145 \\
\hline $\begin{array}{l}\% \text { Growth rate, } \\
\text { GDP (constant 2010 US \$) }\end{array}$ & 7.3 & 11.7 & 6.3 & 3.7 & 2.4 & 1.7 & 7.8 & 4.4 & 5.0 \\
\hline $\begin{array}{l}\text { \% Growth rate, } \\
\text { Mean Lights (DN) }\end{array}$ & 4.0 & 3.9 & 3.9 & 3.9 & 0.8 & 2.9 & 3.2 & 2.9 & 3.5 \\
\hline $\begin{array}{l}\text { \% Growth rate, } \\
\text { Electric power consumption } \\
\text { kWh per capita) }\end{array}$ & 3.1 & 0.2 & 1.5 & 1.8 & 0.7 & 1.3 & 4.1 & 0.8 & -1.5 \\
\hline
\end{tabular}


Table 1 (continue)

\begin{tabular}{|c|c|c|c|c|c|c|c|c|}
\hline Statistics & Poland & Romania & Russia & Slovakia & Tajikistan & Turkmenistan & Ukraine & Uzbekistan \\
\hline$\%$ Area unlit $(D N=0)$ & 17.3 & 47.0 & 92.5 & 28.5 & 89.9 & 91.9 & 58.4 & 82.7 \\
\hline $\begin{array}{l}\% \text { Urban area } \\
(10 \leqslant D N \leqslant 63)^{*}\end{array}$ & 36.2 & 16.7 & 25.7 & 35.2 & 17.0 & 24.6 & 15.0 & 29.2 \\
\hline \%o Top-coded area $(D N=63)^{*}$ & 1.64 & 0.44 & 0.19 & 0.37 & 0.00 & 0.18 & 0.18 & 0.38 \\
\hline $\operatorname{Mean}(D N)$ & 11.36 & 7.58 & 9.75 & 10.66 & 7.29 & 9.16 & 7.08 & 9.66 \\
\hline St. Dev. $(D N)$ & 10.19 & 7.77 & 10.65 & 9.04 & 7.04 & 10.32 & 7.61 & 9.72 \\
\hline Second quartile $(D N)$ & 7.9 & 5.6 & 5.9 & 7.7 & 5.2 & 5.3 & 4.8 & 6.4 \\
\hline Gini $(D N)$ & 0.401 & 0.385 & 0.461 & 0.380 & 0.379 & 0.473 & 0.406 & 0.430 \\
\hline Bonferroni $(D N)$ & 0.496 & 0.467 & 0.549 & 0.474 & 0.462 & 0.562 & 0.483 & 0.525 \\
\hline $\begin{array}{l}\text { Population density } \\
\text { (population/pixel) }\end{array}$ & 64.6 & 52.8 & 3.5 & 62.3 & 33.3 & 6.6 & 44.1 & 38.8 \\
\hline \begin{tabular}{|l|}
$\begin{array}{l}\text { GDP per capita, PPP } \\
\text { (constant } 2011 \text { international \$) }\end{array}$ \\
\end{tabular} & 18931 & 15469 & 20498 & 21725 & 1839 & 8133 & 7261 & 3546 \\
\hline $\begin{array}{l}\text { \% Growth rate, GDP (constant } \\
2010 \text { US \$) }\end{array}$ & 3.6 & 3.8 & 4.5 & 4.2 & 8.0 & 8.7 & 3.7 & 7.2 \\
\hline $\begin{array}{l}\text { \% Growth rate, } \\
\text { Mean Lights }(D N)\end{array}$ & 3.1 & 3.5 & 3.1 & 1.6 & 2.9 & 3.9 & 3.4 & 1.9 \\
\hline $\begin{array}{l}\text { \% Growth rate, } \\
\text { Electric power consumption } \\
\text { (kWh per capita) }\end{array}$ & 1.5 & 1.8 & 1.8 & 0.4 & -1.9 & 3.2 & 2.0 & -0.6 \\
\hline
\end{tabular}

Statistics are calculated averaging data over the period 2000-2013.

Rates of growth are calculated with the compound interest formula over the period 2013-2000.

* Percentages calculated on total lit area.

In "-stan countries" a high fraction of pixels, generally above $90 \%$, is unlit. This is a characteristic in common with Russia, where the unlit area is a $92.5 \%$ of the entire territory. This might be the result represent of a problem in light measurement, as in areas with low population density but with production capacity, lighting may melt into background or be totally absent. Changes in light sources themselves, e.g. a transition from incandescent light bulbs to energy saving technologies and use of LED lamps, might also hamper the interpretation of our results. According to the International Energy Agency, IEA, in 2005 about $19 \%$ of the world energy consumption was related to lighting, and the energy saving capacity is assessed at the level of 30-50\% [19].

The lit area is predominant in most Eastern Europe countries, notably Czechia (95.0\%), Poland (82.7\%), Slovakia (71.5\%), Hungary (63.2\%), Bulgaria (54.0\%) and Romania (53.0\%).

Czechia, Poland and Slovakia show a relatively high degree of urbanization and, in general, percentages of lit pixels - in the frequencies over 10 $D N$ - larger than $35 \%$. Top-coded areas are virtually non-existent in Kazakhstan, Moldova, Kyrgyzstan and Tajikistan. With the exception of Moldova, these countries show the lowest levels of population densities in the whole region.
Overall, higher values of mean lights tend to be associated with higher variability among frequencies. Higher mean values of $D N$ are found in richer realities having top GDP per capita values in terms of PPPs, Czechia, Poland, Slovakia, Hungary and Russia, showing a clearly positive correlation between lights and GDP, which seems at odds with Martinez [20] findings of a negative relation between GDP and night-time lights. In this respect, electricity consumption growth rates data seem less correlated with GDP changes than satellite information on light average growths, and give misleading indications over the whole period i. e. in Azerbaijan, Moldova, Tajikistan and Uzbekistan.

Among the poorest and relatively sparsely populated countries of CIS, like Kyrgyzstan and Tajikistan, a great percentage of pixels are unlit, the average intensity of lights is low (below 8.0), the degree of urbanization shows the minimum values in the region, and top-coded areas are practically absent.

While richer countries tend to have higher average digital numbers, geography and population density also play strong roles. The mean $D N$ reaches its peak in richer realities, notably Eastern Europe countries, which show the highest levels of GDP indicators among the countries in the sample. For these two countries, the indicators in Table 1 display a quite 
similar pattern: low percentages of unlit area, relatively strong urbanization levels and higher values of light concentration, average percentage of top-coded areas, and relatively high population density.

Cross-section and panel comparisons usually perform better among countries with similar culture in terms of use of lights (i. e. energy-saving policies), geographical characteristics, population density, and top-coding magnitude.

As clearly evidenced from the descriptive analyses above and the indications emerging from Table 1, this is not completely the case in our sample of countries, which however show, in their distinct trajectories and patterns, especially those of Eastern Europe and CIS countries, some sub-regional commonalities and trends.

In the empirical part of this work, we will also explore whether changes in dispersion measures (like the Gini and the Bonferroni indices, the inter-quintile as well as the standard deviation of lights), the degree of urbanization, the fraction of unlit and top-coded area, contribute additionally in modelling and forecasting GDP growth and PPPs measures and map them at sub-national levels.

\section{Model and Empirical Results}

The analytical approach used here is similar to the one proposed in [1], who in their pioneering work used a panel model with country and year effects to predict GDP at the international level through night lights, and where country effects controlled for factors like lighting technology and investment in outdoor lighting, whereas year effects monitored differences in light sensitivity across the satellites and changes in global external conditions, like technology and economic conditions.

In our applications, we estimate a panel model where the dependent variable, $y_{i, t}$, represents GDP, and the $x_{i, t}$ are the explanatory variables, defined through different night-lights metrics, population and energy consumption data.

The measures of GDP considered are those that permit, based on model fitted data, to estimate PPP measures, which are not directly supposed to be in relation with measures of night lights. These are GDP in current US dollars and in PPP.

Concretely, the various steps followed in the analyses are as follows: (a) Identification of the best performing series in each group of night-light-based indicators (standard measures, dispersion indices, measures of urbanization, other series, including population and energy consumption) using pooling regressions;

(b) Estimation of panel data models for both GDP in current US dollars and PPP (current international US dollars) with national data for the 17 countries;

(c) Conversion of the estimated values of the model for GDP in current US dollar to local currency;

(d) Derivation of implicit PPP estimates from the two models and comparison with World Bank PPP time series estimates;

(e) Application of the coefficients obtained with the estimation of the national model for GDP in current US dollars to sub-national night-lights indicators available at NUTS 1 level;

(f) Comparison of the data estimated in step (e) with the official regional available data published by countries to verify the existence of a MAU problem; and

(g) Use of the estimated coefficient to obtain further space disaggregation of the interest series, namely GDP and PPP.

Let us analyse, step by step, how the procedure above was carried out for our data-set. Preliminary analyses on our two GDP series, $y_{i, t}$, suggest that based on [21] CIPS tests -, the panel should be estimated in first differences.

The preliminary analyses made using pooled regressions on the rate of growth against standard measures of lights (sum and mean in log terms, and the corresponding per-capita values), dispersion measures (the Gini and the Bonferroni indices, the mean log deviation, the inter-quintile difference as well as the standard deviation of lights), different measures of urbanization (the night-light intensity index, $N L I$, and its two components, the urban light index, $U L I$, with lower threshold at 7 or $10 \mathrm{DN}$ ), population density, as well as energy consumption, shows that the series performing better are the sum of light per-capita, the ratio of standard deviation to mean of lights, the Gini concentration index, and the urban light index, with $D N=10$. Given the upwards trend characterizing lights and GDP data, both series are expressed in logdifference in our panels, while other series, for their bounded characteristic, are considered in level form.

A flavour of our data-set, composed by 221 observations when expressed in growth rates, is provided in the conditioning plots reported in Figures 2 and 3. 

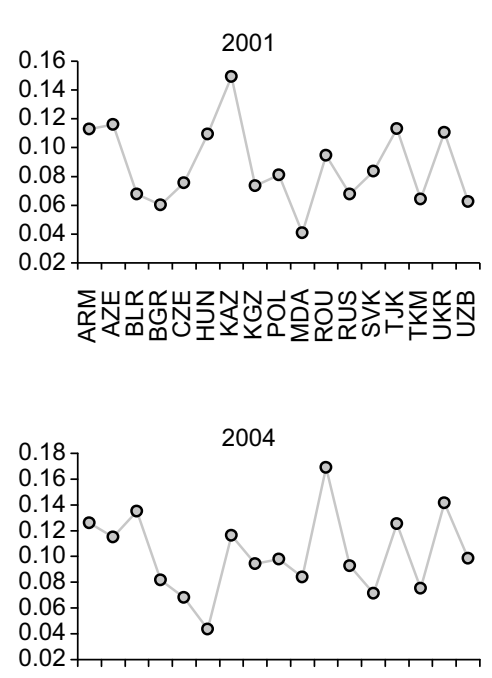

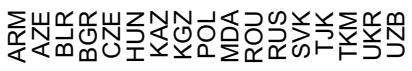
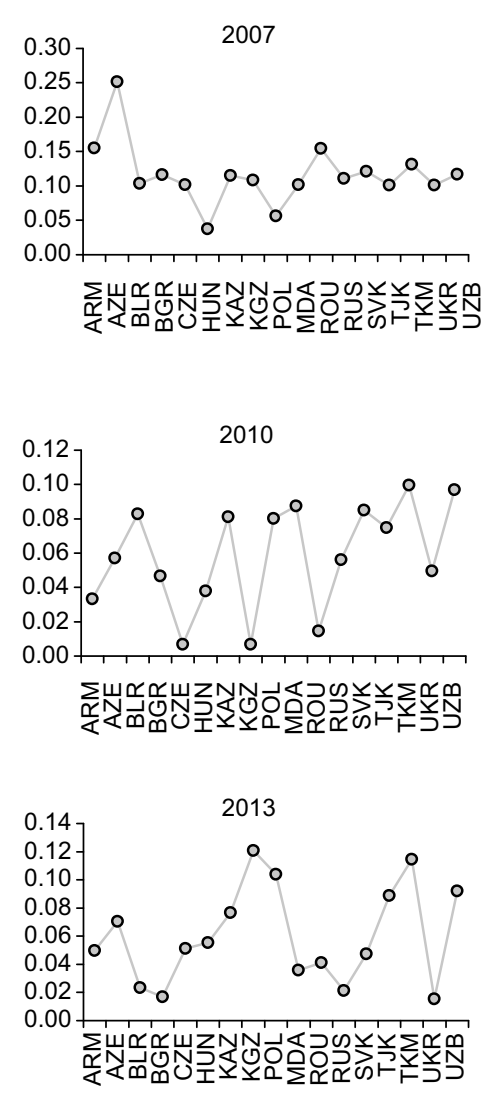
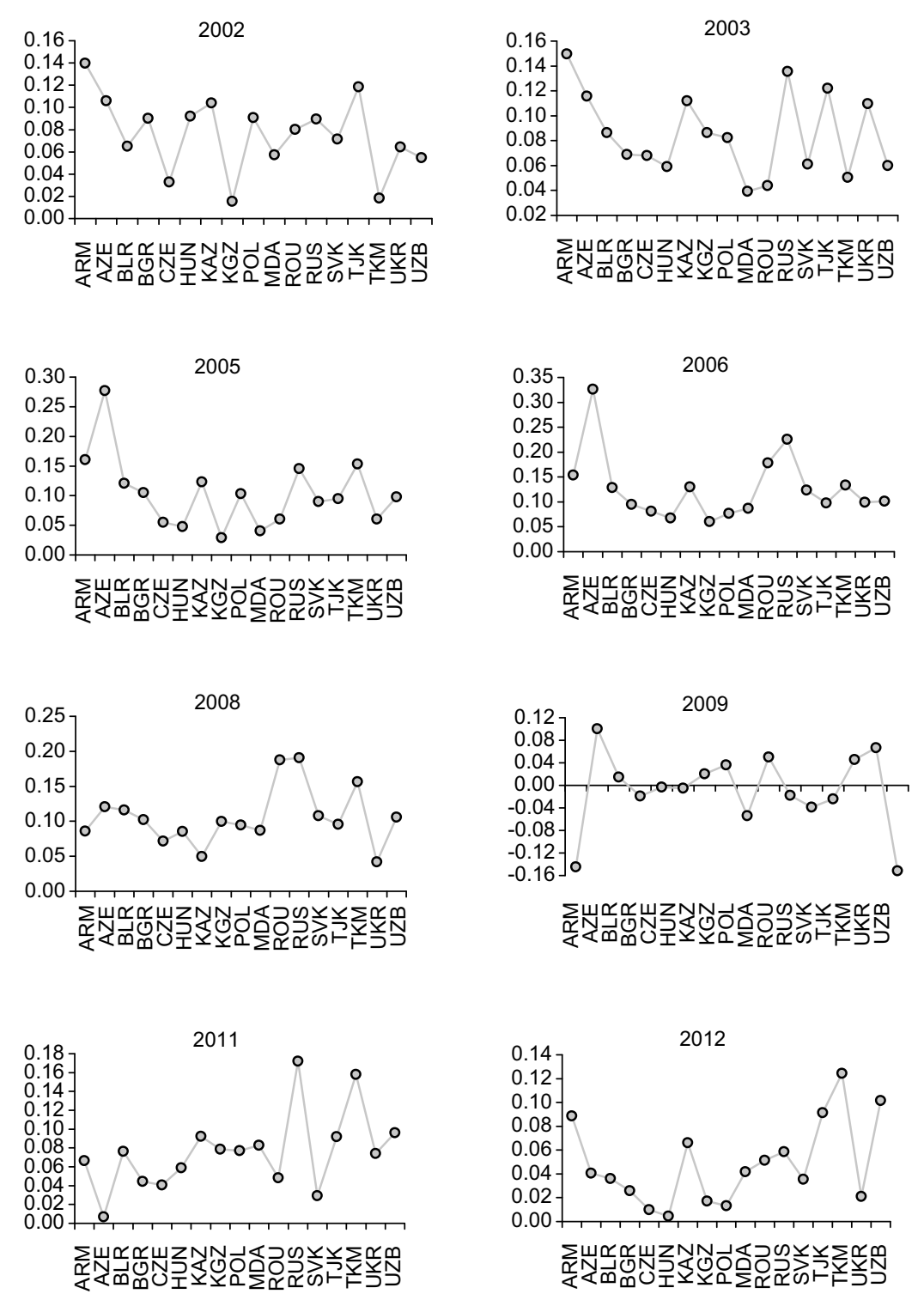

Figure 2. Conditioning Plots of GDP in PPP (Current International US Dollars), by Years, 2001-2013 


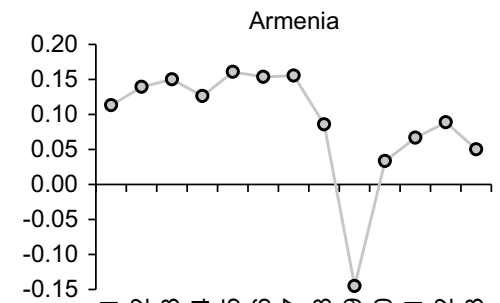

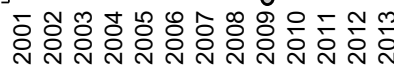

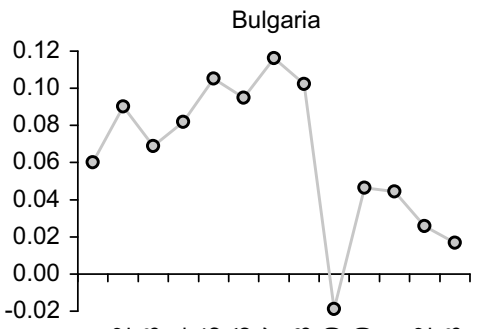

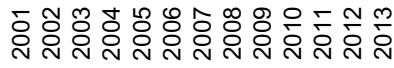

Kazakhstan

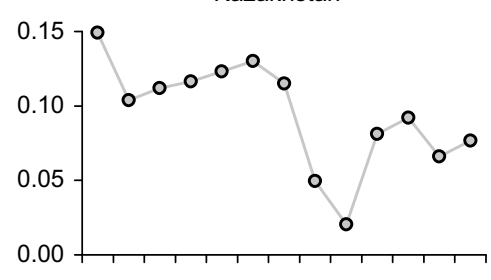

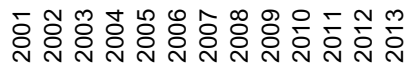

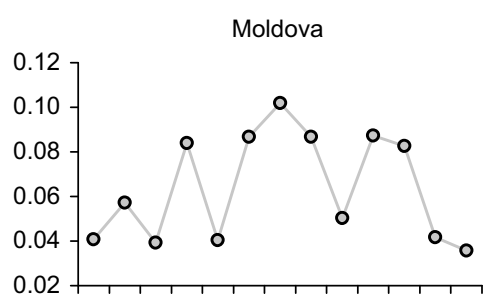

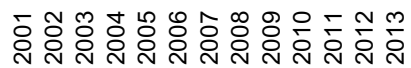

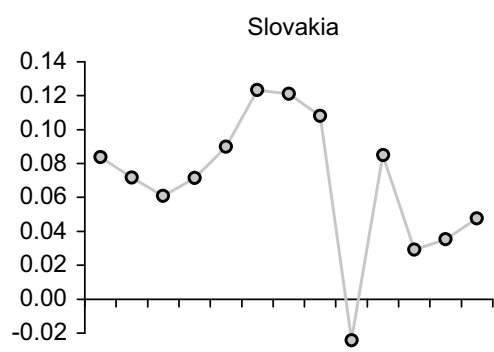

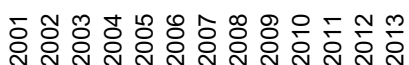

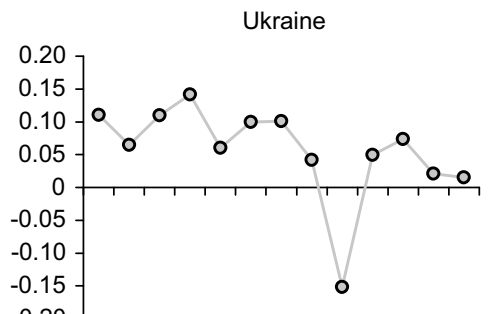

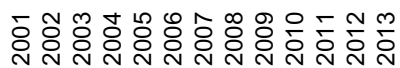

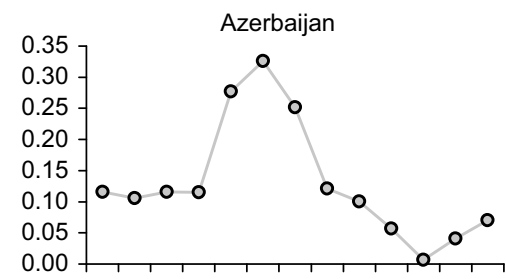

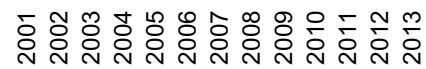

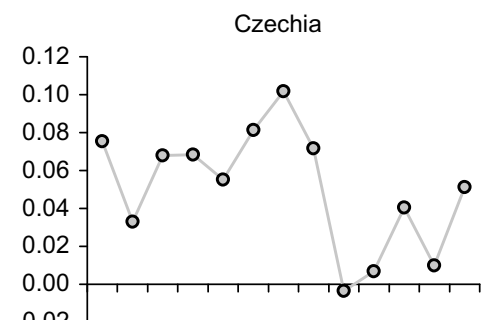

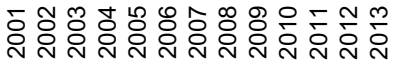

Kyrgyzstan

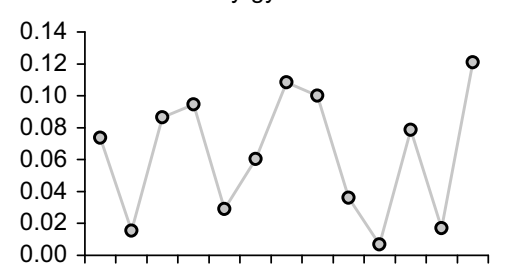

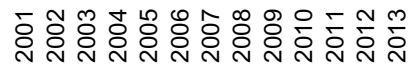

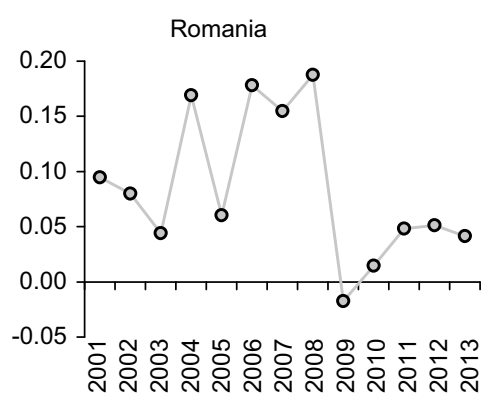

Tajikistan

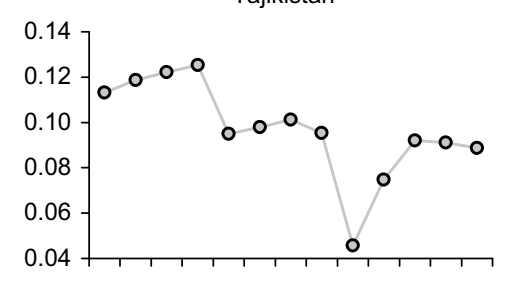

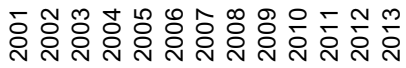

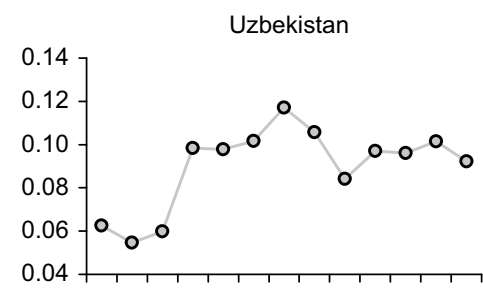

চ্்

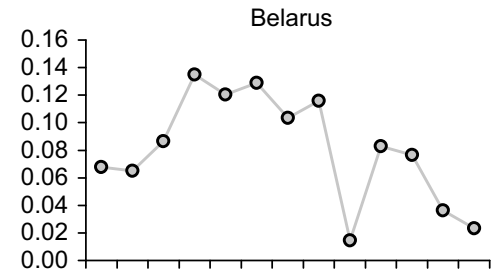

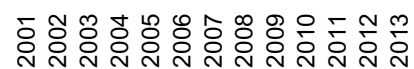

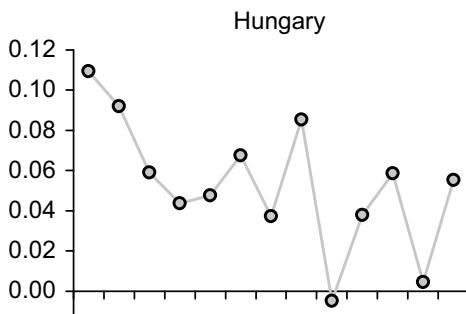

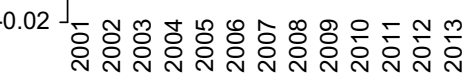

Poland

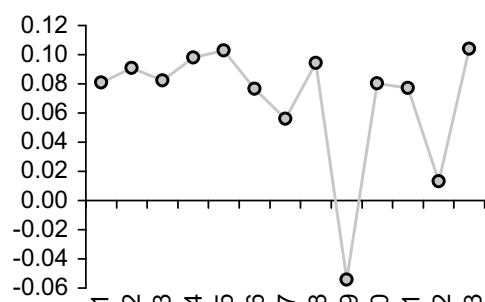

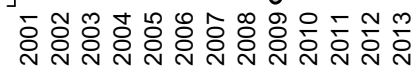

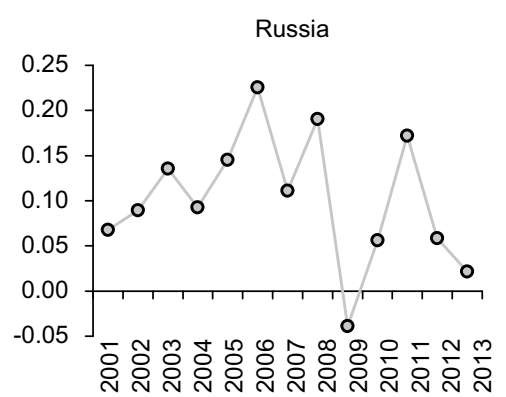

Turkmenistan

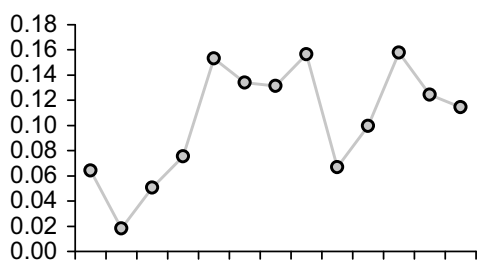

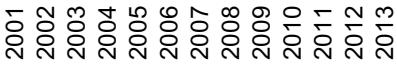

Figure 3. Conditioning Plots of GDP in PPP (Current International US Dollars), by Country, 2001-2013 
Further insights on the heterogeneity across years and countries are provided in Figure 4, where it emer-

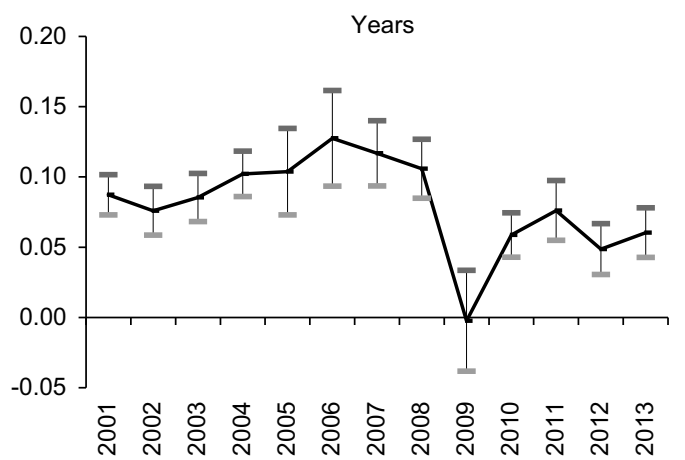

ges a certain degree of country and time-heterogeneity along the reference period.

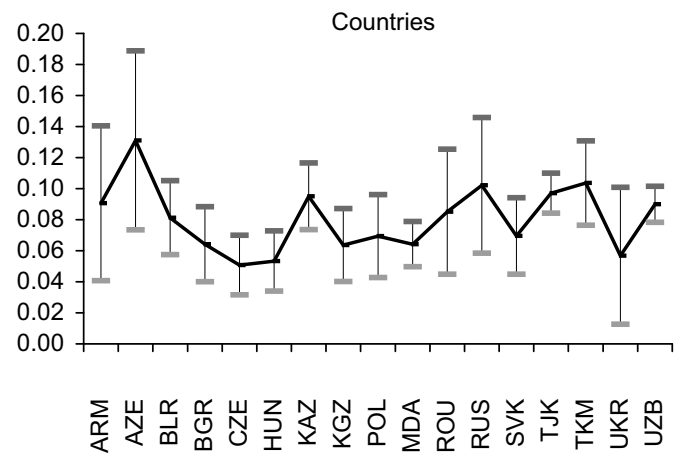

Figure 4. Heterogeneity Across Years and Countries of GDP in PPP (Current International US Dollars), 2001-2013

The results obtained from the estimations of pooled linear regression, random and fixed effects models, reported in Table 2, show a strong significance of the exogenous variables identified above for both GDP series.

Main Results of the Pooled Regressions and Panel Fixed and Random Effect Models, 2001-2013

\begin{tabular}{|l|c|c|c|c|c|c|}
\hline \multirow{2}{*}{} & \multicolumn{2}{|c|}{ GDP, PPP (current international \$) } & \multicolumn{3}{c|}{ GDP (current US \$) } \\
\cline { 2 - 7 } & Pooled & Fixed Effect & Random Effect & Pooled & Fixed Effect & Random Effect \\
\hline \multirow{2}{*}{ Constant } & $-0.1167^{* *}$ & & $-0.1834^{* *}$ & $-0.2395^{*}$ & & $-0.3065^{* *}$ \\
& $(0.0421)$ & - & $(0.0574)$ & $(0.0954)$ & - & $(0.1158)$ \\
\hline \multirow{2}{*}{$\ln (S L / P O P)$} & $0.0542^{* * *}$ & $0.0565^{* * *}$ & $0.0548^{* * *}$ & $0.1652^{* * *}$ & $0.1668^{* * *}$ & $0.1646^{* * *}$ \\
& $(0.0158)$ & $(0.0149)$ & $(0.0150)$ & $(0.0360)$ & $(0.0348)$ & $(0.0349)$ \\
\hline \multirow{2}{*}{$S D L / M L$} & $0.1722^{* * *}$ & $0.1579^{* * *}$ & $0.1684^{* * *}$ & $0.6659^{* * *}$ & $0.6162^{* * *}$ & $0.6533^{* * *}$ \\
& $(0.0376)$ & $(0.0360)$ & $(0.0359)$ & $(0.0851)$ & $(0.0839)$ & $(0.0833)$ \\
\hline \multirow{2}{*}{$G N$} & $0.3375^{* * *}$ & $0.3273^{* * *}$ & $0.3312^{* * *}$ & $0.9406^{* * *}$ & $1.0367^{* * *}$ & $0.9797^{* * *}$ \\
& $(0.0694)$ & $(0.0713)$ & $(0.0695)$ & $(0.1572)$ & $(0.1661)$ & $(0.1590)$ \\
\hline \multirow{2}{*}{$U L I(D N \geqslant 10)$} & 0.0017 & $0.0088^{* *}$ & 0.0038 & -0.0003 & 0.0122 & 0.0013 \\
& $(0.0015)$ & $(0.0027)$ & $(0.0019)^{*}$ & $(0.0035)$ & $(0.0063)$ & $(0.0040)$ \\
\hline Nr. of obs. & 221 & 221 & 221 & 221 & 221 & 221 \\
\hline$R^{2}$ & 0.297 & 0.324 & 0.303 & 0.425 & 0.460 & 0.434 \\
\hline$F$ & $22.855^{* * *}$ & $24.012^{* * *}$ & $23.474^{* * *}$ & $39.946^{* * *}$ & $42.529^{* * *}$ & $41.496^{* * *}$ \\
\hline
\end{tabular}

$R^{2}$ not corrected. ${ }^{*} p<.05,{ }^{* *} p<.01,{ }^{* * *} p<.001$.

Country (excluding the pooled models) and time dummies are included in the estimated models.

The Hausman tests statistics of 6.827 and 7.160 respectively for GDP in PPP (current international US dollars) and GDP at current US dollars, with their associated p-values of 0.145 and 0.128 , lead to accept the null of random effects against a fixed effects model, while Breusch-Pagan Lagrange Multiplier tests for random effects uniformly reject the null that variances across entities are zero in all models considered.

After conversion of the estimated values of the model for GDP in current US dollar to local currency using official exchange rates available in the World Bank data-base, implicit PPP estimates are obtained from the two models using the coefficients reported in Table 2, and comparisons are made with World Bank
PPP time series estimates, after reporting estimates of growth rates to level variables for the two measures of GDP. The correlation of the two series with official PPPs is strong, equal over the whole 2000-2013 sample and for all data obtained for the 17 countries, to 0.981 . Similar results are obtained for GDP measures used in the analyses.

As an example, we graph in Figure 5 the two lines of estimated PPPs from our model and the data estimated by the World Bank data-base. The two lines are very close each other, with similar values at the beginning and the end of the estimation period, but with a slight divergence during the period of the international financial crisis, 2008-2010. 


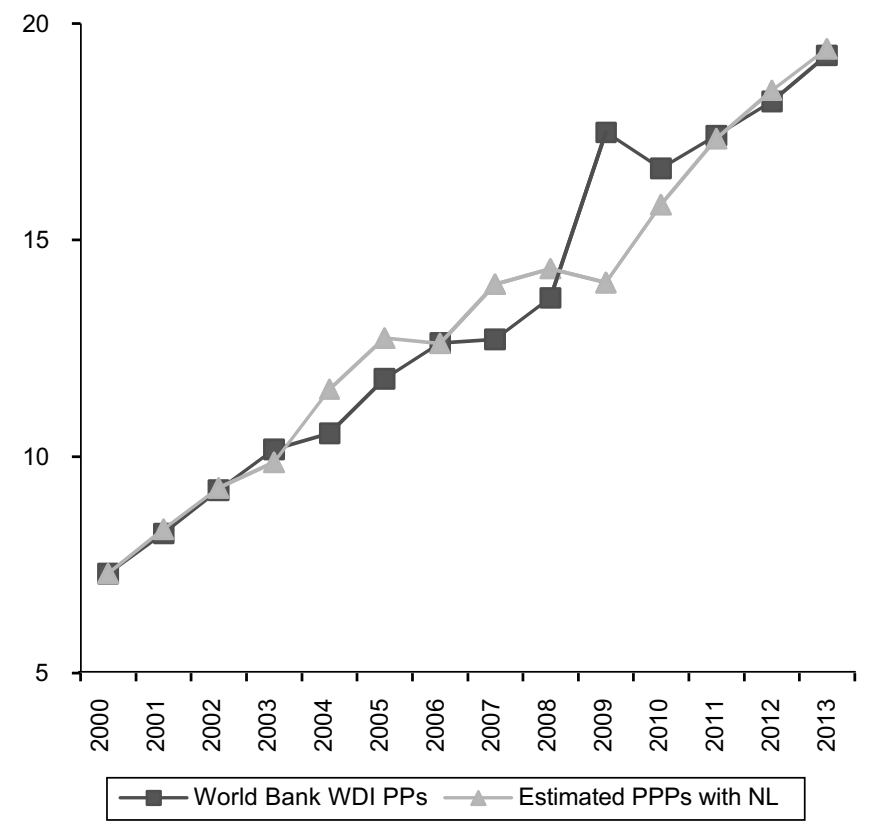

Figure 5. Comparison of National PPPs Estimated by the World Bank with Those Estimated with the Panel Regression Model Based on Night Lights, Russian Federation, 2000-2013

When the estimated coefficients are applied to subnational lights indicators at the level- 1 administrative official boundaries, and the results compared with the available data on GDP at current US dollars, the correlation between the official and estimated level data show values close to those obtained for PPPs (step (f) of our procedure), thus making it feasible to proceed to step $(\mathrm{g})$.

Mapping of GDP and PPP data are not reported here in order to save space, but will be provided by authors upon request, either in data format or in the form of summary choropleth maps.

\section{Conclusions}

Spatially disaggregated maps of GDP and PPP, especially if updated on an annual basis or at higher frequency, would be extremely beneficial for tracking the effectiveness of policy efforts in specific areas or, for example, evaluating the consequences of natural disasters, conflicts or other general policy purposes. Satellite images in the form of night lights could help in better understanding those economic phenomena and their space-temporal dynamics.

The sub-national analyses carried out in this paper had a twofold objective. First, to examine the feasibility of applying the country level approach to the sub-national level on a country-by-country basis, and second to explore the opportunity of using global/re- gional models for countries where sub-national data on GDP are either missing or deemed to be unreliable. Furthermore, attempts to estimate sub-national PPPs data, although important to identify space price dynamics and measuring, amongst others, poverty lines at sub-national level, so far have provided quite unsatisfactory results, whilst the way to obtain information through traditional approaches is practically unfeasible for costs reasons.

The analyses and outcomes of this research rest on the assumption that coefficients describing GDP at the national level continue being of use at the finer disaggregated geographical level.

The MAUP is a well-known problem in geography and spatial analysis. However, there is scarce research on MAUP's impact in studies that make extensive use of satellite images, particularly those obtained from DMSP images, see e. g. [22]. Indeed, the majority of literature on socio-economic spatial disaggregation through night lights rests on the assumption of negligible MAUP. This is indeed a line for future research on the GDP-PPP-nigh-time images relation, possibly with use of sensitivity analysis, or scaling as an additional dimension to take into consideration [23].

While the OLS is remarkable for its detection of dim lighting over a long time span, the quality of its mapping products could be improved in a number of ways. The main shortcomings of the OLS data include the following, in part resolved by the introduction of the new VIIRS products: (a) granular spatial resolution; (b) lack of on-board calibration; (c) limited dynamic range; (d) signal saturation in urban populated centres; (e) limited data recording and download capabilities; and (f) lack of multiple spectral bands for discriminating lighting types. The use of VIIRS data could clearly improve on the results presented in this paper, permitting estimations and updating of maps at higher frequencies, but longer time series of data would be necessary to obtain sufficient information for use in a panel framework.

The research could also expand by analysing images captured by other non-US satellites. European data on earth observations are another incredible source of statistics information, with Copernicus being perhaps the most ambitious earth observation programme to date. This initiative, headed by the European Commission in partnership with the European Space Agency, is actually providing accurate, timely and easily accessible information.

The information provided by this incredible source of information for Sustainable Development Goals 
monitoring and reporting is in its preliminary phase, but there is an enormous amount of information awaiting for investigation to help shape the future of our planet for the benefit of all, leaving none behind.

\section{References}

1. Henderson J.V., Storeygard A., Weil D.N. Measuring Economic Growth from Outer Space. American Economic Review. 2012;102(2):994-1028. Available from: https:// doi.org/10.1257/aer.102.2.994.

2. Donaldson D., Storeygard A. The View From Above: Applications of Satellite Data in Economics. Journal of Economic Perspectives. 2016;30(4):171-198. Available from: https://doi.org/10.1257/jep.30.4.171.

3. Hu Y., Yao J. Illuminating Economic Growth. IMF Working Papers. WP/19/77. 2019. Available from: https:// www.imf.org/en/Publications/WP/Issues/2019/04/09/I1luminating-Economic-Growth-46670.

4. Elvidge C.D. et al. National Trends in Satellite Observed Lighting 1992-2012. In: Q. Weng (ed.). Global Urban Monitoring and Assessment Through Earth Observation. Boca Raton, FL: CRC Press; 2014. Chap. 6. P. 97-119.

5. Bickenbach F. et al. Night Lights and Regional GDP. Review of World Economics. 2016;152(2):425-447. Available from: https://doi.org/10.1007/s10290-016-0246-0.

6. Addison D.M., Stewart B.P. Nighttime Lights Revisited: The Use of Nighttime Lights Data as a Proxy for Economic Variables. Policy Research Working Paper. WPS7496. World Bank; 2015.

7. Croft T.A. The Brightness of Lights on Earth at Night, Digitally Recorded by DMSP Satellite. Stanford Research Institute Final Report prepared for the U.S. Geological Survey. Palo Alto, CA; 1979. Available from: https://doi.org/10.3133/ofr80167.

8. Doll C.N.H. CIESIN Thematic Guide to Night-Time Light Remote Sensing and its Applications. Center for International Earth Science Information Network (CIESIN), Columbia University, Palisades, NY, USA; 2008. Available from: http://pure.iiasa.ac.at/id/eprint/8704/.

9. Huang Q. et al. Application of DMSP/OLS Nighttime Light Images: A Meta-Analysis and a Systematic Literature Review. Remote Sensing. 2014;(6):6644-6866. Available from: https://doi.org/10.3390/rs6086844.

10. Elvidge C.D. et al. Why VIIRS Data are Superior to DMSP for Mapping Nighttime Lights. Proceedings of the Asia-Pacific Advanced Network. 2013;(35):62-69. Available from: http://dx.doi.org/10.7125/APAN.35.7.

11. Small C., Elvidge C.D. Night on Earth: Mapping Decadal Changes of Anthropogenic Night Light in Asia. International Journal of Applied Earth Observation and Geo- information. 2013;(22):40-52. Available from: https://doi. org/10.1016/j.jag.2012.02.009.

12. Li X., Zhou Y. A Stepwise Calibration of Global DMSP/OLS Stable Nighttime Light Data (1992-2013). Remote Sensing. 2017;9(6):637. Available from: https://doi. org/10.3390/rs9060637.

13. Gini C. Sulla Misura Della Concentrazione e Della Variabilita dei Caratteri. Atti del Reale Istituto Veneto di Scienze, Lettere ed Arti. 1914;(LXXIII):1203-1248. (English translation in: Metron - International Journal of Statistics. 2005; LXIII(1):3-38).

14. Bonferroni C. Elementi di Statistica Generale. Firenze: Libreria Seber; 1930.

15. Tarsitano A. The Bonferroni Index of Income Inequality. In Dagum C., Zenga M. (eds.) Income and Wealth Distribution, Inequality and Poverty. Berlin: Springer-Verlag; 1989. P. 228-242.

16. Imhoff M.L. et al. A Technique for Using Composite DMSP/OLS 'City Lights' Satellite Data to Map Urban Area. Remote Sensing of Environment. 1997;61(3):361370. Available from: https://doi.org/10.1016/S00344257(97)00046-1.

17. Yi K. et al. Mapping and Evaluating the Urbanization Process in Northeast China Using DMSP/OLS Nighttime Light Data. Sensors. 2014;14(2):3207-3226. Available from: https://www.mdpi.com/1424-8220/14/2/3207.

18. Yang M. et al. A Study of Urbanization in China Based on Regionalization Using DMSP/OLS Night Light Imagery. 2009 Joint Urban Remote Sensing Event. Shanghai: IEEE; 2009. P. 1-7. Available from: https://doi. org/10.1109/URS.2009.5137530.

19. IEA. Light's Labour's Lost: Policies for Energy-Efficient Lighting. Paris: OECD Publishing. 2006. Available from: https://doi.org/10.1787/9789264109520-en.

20. Martinez L.R. How Much Should We Trust the Dictator's GDP Growth Estimates? University of Chicago Working Paper, 2019. Available from: http://dx.doi. org/10.2139/ssrn.3093296.

21. Pesaran M.H. A Simple Panel Unit Root Test in the Presence of Cross Section Dependence. Journal of Applied Econometrics. 2007;22(2):265-312. Available from: https://onlinelibrary.wiley.com/doi/epdf/10.1002/ jae.951.

22. Chen X., Nordhaus W.D. VIIRS Nighttime Lights in the Estimation of Cross-Sectional and Time-Series GDP. Remote Sensing. 2019;11(9):1057. Available from: https://doi.org/10.3390/rs11091057.

23. Wu J., Li H. Concepts of Scale and Scaling. In: Wu J., Li H., Loucks O.L., Jones K.B. (eds.) Scaling and Uncertainty Analysis in Ecology - Methods and Applications. Dordrecht: Springer; 2016. P. 3-15.

\section{About the authors}

M. Simona Andreano - Professor, Mercatorum University. 10, Piazza Mattei, Rome, IT-00186, Italy. E-mail: s.andreano@unimercatorum.it. ORCID: https://orcid.org/0000-0003-0748-1524.

Roberto Benedetti - Professor, D’Annunzio University of Chieti-Pescara. 42, Viale Pindaro, Pescara, IT-65127, Italy. E-mail: benedett@unich.it. ORCID: https://orcid.org/0000-0003-0763-819X. 
Federica Piersimoni - Senior Statistician, Italian National Institute of Statistics (Istat). 16, Via Cesare Balbo, Rome, IT-00184, Italy. E-mail: piersimo@istat.it. ORCID: https://orcid.org/0000-0001-7075-4893.

Giovanni Savio - Senior Statistician, United Nations Economic Commission for Latin America and the Caribbean (UN-ECLAC). Av. Dag Hammarskjöld 3477, Vitacura, Santiago de Chile, Chile. E-mail: giovanni.savio@un.org.

\section{Acknowledgements}

The authors are grateful to Yuri Beletski for the comments received on an earlier version of this paper, presented at the HSE-IARIW Conference on Experiences and Challenges in Measuring Income and Wealth in Eastern Europe and CIS Countries, September 2019, Moscow.

Thanks are also due to Andrey Kosarev for the encouragement in developing this research and the advices provided.

\section{Информация об авторах}

Андреано М. Симона - профессор, Университет Меркаторум. IT-00186, г. Рим, пл. Маттеи, 10, Италия. E-mail: s.andreano@unimercatorum.it. ORCID: https://orcid.org/0000-0003-0748-1524.

Бенедетти Роберто - профессор, Университет им. Г. Д’Аннунцио Кьети-Пескара. IT-65127, г. Пескара, пр-т Пиндаро, 42, Италия. E-mail: benedett@unich.it. ORCID: https://orcid.org/0000-0003-0763-819X.

Пьерсимони Федерика - старший статистик, Национальный институт статистики Италии (Истат). IT-00184, г. Рим, ул. Чезаре Бальбо, 16, Италия. E-mail: piersimo@istat.it. ORCID: https://orcid.org/0000-00017075-4893.

Савио Джованни - старший статистик, Экономическая комиссия ООН для Латинской Америки и Карибского бассейна (ЭКЛАК). 763041, г. Сантьяго-де-Чили, Витакура, пр-т Дага Хаммаршёльда 3477, Чили. E-mail: giovanni.savio@un.org.

\section{Благодарности}

Авторы выражают благодарность Юрию Белецкому за замечания, полученные в отношении ранней версии статьи, представленной на Международной конференции IARIW-ВШЭ «Опыт и вызовы в изучении доходов и благосостояния в странах Восточной Европы и СНГ», которая прошла в сентябре 2019 г. в г. Москве.

Благодарим также Андрея Косарева за поддержку в разработке этого исследования и предоставленные советы. 